Check for updates

Cite this: RSC Adv., 2020, 10, 43751

\title{
Cationic gemini surfactant stimulates amyloid fibril formation in bovine liver catalase at physiological pH. A biophysical study
}

\author{
Javed Masood Khan, (D) *a Ajamaluddin Malik, ${ }^{\text {b } M d . ~ T a b i s h ~ R e h m a n, ~}{ }^{c}$ \\ Mohamed F. AlAjmi, ${ }^{c}$ Mohammad Z. Ahmed, ${ }^{c}$ Ghada Obaid Almutairi, ${ }^{b}$ \\ Md. Khalid Anwer ${ }^{d}$ and Rizwan Hasan Khan ${ }^{\mathrm{e}}$
}

Surfactant molecules stimulate amyloid fibrillation and conformational switching in proteins but the mechanisms by which they accomplish these effects are unclear. A cationic gemini surfactant, $\mathrm{C}_{16} \mathrm{C}_{4} \mathrm{C}_{16} \mathrm{Br}_{2}$, with two positively charged heads and two-16C hydrophobic tails induces the amyloid fibrillation of bovine liver catalase $(\mathrm{BLC})$ in vitro at physiological $\mathrm{pH}$. The $\mathrm{BLC}$ transformed into amyloid aggregates in the presence of low concentrations (2-150 $\mu \mathrm{M}$ ) of $\mathrm{C}_{16} \mathrm{C}_{4} \mathrm{C}_{16} \mathrm{Br}_{2}$ at $\mathrm{pH} 7.4$, as confirmed by the use of several biophysical techniques (Rayleigh light scattering (RLS), intrinsic fluorescence, thioflavin T fluorescence (ThT), far-UV circular dichroism, and transmission electron microscopy). The secondary structure of BLC also changed according to the concentration of $\mathrm{C}_{16} \mathrm{C}_{4} \mathrm{C}_{16} \mathrm{Br}_{2}$ : the $\alpha$-helical structure of $\mathrm{BLC}$ decreased in the presence of $2-100 \mu \mathrm{M}$ of $\mathrm{C}_{16} \mathrm{C}_{4} \mathrm{C}_{16} \mathrm{Br}_{2}$ but at concentrations above $200 \mu \mathrm{M}$ BLC regained a $\alpha$-helical structure very similar to the native BLC. In silico molecular docking between BLC and $\mathrm{C}_{16} \mathrm{C}_{4} \mathrm{C}_{16} \mathrm{Br}_{2}$ suggest that the positively charged heads of the surfactant interact with Asp127 through attractive electrostatic interactions. Moreover, a Pi-cation electrostatic interaction and hydrophobic interactions also take place between the tails of the surfactant and BLC. The stability of the BLC $-\mathrm{C}_{16} \mathrm{C}_{4} \mathrm{C}_{16} \mathrm{Br}_{2}$ complex was confirmed by performing a molecular dynamics simulation and evaluating parameters such as root mean square deviation (RMSD), root mean square fluctuation (RMSF), radius of gyration $\left(R_{\mathrm{g}}\right)$, and solvent accessible surface area (SASA). Apart from its aggregation inducing properties, the gemini surfactant itself causes toxicity to the cancerous cell (A549): which is confirmed by MTT assay. This work delivers new insight into the effect of cationic gemini surfactants in amyloid aggregation and paves the way to the rational design of new anti-amyloidogenic agents.

Received 3rd September 2020 Accepted 9th November 2020

DOI: $10.1039 / d 0 r a 07560 d$

rsc.li/rsc-advances

\section{Introduction}

Amyloidosis is caused by the deposition of globular soluble proteins into insoluble amyloid-like structures in the extracellular spaces, causing cell death and tissue degeneration. ${ }^{1}$ More than 25 types of proteins and polypeptides are associated with several neuronal diseases. For instance, the $A \beta$ peptide is directly linked to Alzheimer's disease, the PrP protein is related to transmissible spongiform encephalopathies, familial amyloidoses are due to the misfolding of transthyretin and

\footnotetext{
${ }^{a}$ Department of Food Science and Nutrition, Faculty of Food and Agricultural Sciences, King Saud University, 2460, Riyadh 11451, Saudi Arabia. E-mail:jmkhan@ksu.edu.sa; javedjmk@gmail.com

${ }^{b}$ Department of Biochemistry, College of Science, King Saud University, Riyadh, Saudi Arabia

'Department of Pharmacognosy, College of Pharmacy, King Saud University, Riyadh, Saudi Arabia

${ }^{d}$ Department of Pharmaceutics, College of Pharmacy, Prince Sattam Bin Abdulaziz University, Alkharj, 11942, Saudi Arabia

'Interdisciplinary Biotechnology Unit, Aligarh Muslim University, Aligarh, U.P., India
}

lysozyme, and so on. ${ }^{2,3}$ There are two types of amyloidogenic proteins: (i) globular proteins with a defined tertiary structure and (ii) proteins devoid of tertiary structures (disordered proteins). ${ }^{2,4}$ Amyloid fibrils are ordered aggregates with a "cross$\beta$ " core structure made up of $\beta$-sheets arrays and arranged parallel to the long axis of the fibrils. ${ }^{5}$ Globular proteins partially unfold at low $\mathrm{pH}$ and high temperature and then form well-defined amyloid-like aggregates. ${ }^{6,7}$ Many proteins have a strong tendency to form amyloid or amyloid-like aggregates by interacting with surfactants and lipids at physiological and low $\mathrm{pH}^{8,9}$ Generally, anionic surfactants stimulate amyloid fibril formation in proteins. ${ }^{10}$ Negatively charged surfactants and phospholipids interact with proteins via electrostatic and hydrophobic interaction and stimulate amyloid fibril formation. ${ }^{11,12}$ Monomeric sodium dodecyl sulfate (SDS) binds to proteins and changes their local conformation, however, at micellar concentrations it causes more global change and the proteins unfold. ${ }^{13}$ Several anionic surfactants such as sodium dodecyl sulfate, sodium octyl sulfate, and sodium deoxycholate, accelerate amyloid fibrillation of $\beta 2$-microglobulin near the 
critical micelle concentration (CMC). ${ }^{14}$ Generally, cationic surfactants do not form electrostatic interactions with proteins but this depends on $\mathrm{pH}^{15}$ Cationic surfactants may also promote amyloidosis. ${ }^{16}$ In this study, we explored the effects of a non-conventional gemini surfactant i.e., bis(cetyldimethylammonium)butane dibromide $\left(\mathrm{C}_{16} \mathrm{C}_{4} \mathrm{C}_{16} \mathrm{Br}_{2}\right)$ on the structures of BLC. The $\mathrm{C}_{16} \mathrm{C}_{4} \mathrm{C}_{16} \mathrm{Br}_{2}$ surfactant is dimeric in nature and consists of two identical amphiphilic moieties (16C) (hydrophobic chains and two polar head groups). A 4C spacer at the head groups connects both the amphiphilic moieties. Gemini surfactants have gained substantial attention due to their unique properties and applications. They have a lower CMC compared to the single-chain conventional surfactants. ${ }^{17}$ Gemini surfactants have several important applications. For example, they are used as an additive in the mitigation and remediation of soils contaminated by organic compounds. Gemini surfactants also emulsify fuels for diesel engines and improve improved engine performance, reduce emissions, and reduce in torque ${ }^{18}$

Besides, they have lower aquatic toxicity compared to the monomeric ones. This lower toxicity may be directly related to the higher hydrophilicity of the gemini surfactants. ${ }^{19}$ They also exhibit extremely high antimicrobial activity against bacteria, viruses, molds, and yeasts and their minimal inhibitory concentrations (MICs) are lower than that the monomeric conventional surfactants. ${ }^{20} \mathrm{Gemini}$ surfactants are relatively easy to eliminate from the environment as they are more susceptible to alkaline hydrolysis compared to monomeric conventional surfactants. ${ }^{21}$ The hydrophobicity of gemini surfactants also plays an important role in protein-surfactant interactions. ${ }^{22}$

Here, we investigate the effect of the cationic gemini surfactant $\mathrm{C}_{16} \mathrm{C}_{4} \mathrm{C}_{16} \mathrm{Br}_{2}$ on the formation of amyloid fibrils in $\mathrm{BLC}$ at physiological $\mathrm{pH}$. The critical micellar concentrations of gemini $\left(\mathrm{C}_{16} \mathrm{C}_{4} \mathrm{C}_{16} \mathrm{Br}_{2}\right)$ surfactant was found around $0.025 \mathrm{mM}$ in distilled water. ${ }^{23}$ The mechanism by which gemini surfactants stimulate amyloid fibril formation in proteins is reported very less. ${ }^{24,25}$ This motivated us to explore the influence of a gemini surfactant on amyloid fibril formation of BLC at physiological $\mathrm{pH}$.

Catalase is a ubiquitous enzyme found in almost every aerobic organism and it protects cells from the adverse effects of free radicals. BLC is a tetrameric protein with a molecular mass of $240 \mathrm{kDa}$, composed of four identical $(\sim 57 \mathrm{kDa})$ subunits, each possessing a high-spin $\mathrm{Fe}(\mathrm{III})$ protoporphyrin IX. ${ }^{26}$ This enzyme has the highest turnover number $\left(4 \times 10^{7} \mathrm{~s}^{-1}\right)$ and it is not obeying ordinary Michaelis-Menton mechanism. ${ }^{27}$ BLC has many industrial (dairy and textile industries) and medical applications (breakdown the reactive oxygen spices i.e., hydrogen peroxide $\left(\mathrm{H}_{2} \mathrm{O}_{2}\right)$ into $\left.\mathrm{H}_{2} \mathrm{O}\right){ }^{28}$ Catalase is also used as a biosensor for the detection of $\mathrm{H}_{2} \mathrm{O}_{2} \cdot{ }^{29}$

In the current work, we analyzed the conformational changes of BLC proteins when exposed to various concentrations of $\mathrm{C}_{16} \mathrm{C}_{4} \mathrm{C}_{16} \mathrm{Br}_{2}$ at physiological $\mathrm{pH}$. The conformational transition was characterized by the use of spectroscopic, microscopic, and computational techniques. The cytotoxicity effect of gemini surfactant was also evaluated in details.

\section{Experimental section}

\section{Chemicals}

Bovine liver catalase (BLC), and thioflavin-T were purchased from Sigma-Aldrich Chemicals Co. (St. Louis, MO, USA). Human lung cancer cell line A549 (ATCC® CCL-185) was purchased from ATCC. The gemini surfactant $\left(\mathrm{C}_{16} \mathrm{C}_{4} \mathrm{C}_{16} \mathrm{Br}_{2}\right)$ was provided by Dr Amin Mir from the Department of Chemistry, University of Kashmir, Srinagar, India. All other chemicals used were of analytical grade.

\section{BLC stock preparation}

BLC concentration was measured on a PerkinElmer, Lamda 25 spectrophotometer attached with Peltier. The absorbance of BLC was taken at $405 \mathrm{~nm}$ and stock concentrations were calculated using an extinction coefficient $E_{1 \mathrm{~cm}}{ }^{1 \%}$ of $13.5 .^{30}$

\section{Rayleigh light scattering (RLS) measurements}

$\mathrm{C}_{16} \mathrm{C}_{4} \mathrm{C}_{16} \mathrm{Br}_{2}$-induced aggregation of $\mathrm{BLC}$ was assessed by measuring light scattering measurements on a Cary Eclipse fluorescence spectrophotometer (Agilent Technologies) at room temperature. The BLC $\left(0.2 \mathrm{mg} \mathrm{mL}^{-1}\right)$ samples treated with 0 to 750 $\mu \mathrm{M} \mathrm{C}_{16} \mathrm{C}_{4} \mathrm{C}_{16} \mathrm{Br}_{2}$ at $\mathrm{pH} 7.4$ and incubated for $12 \mathrm{~h}$. The incubated samples were excited at $350 \mathrm{~nm}$ and the emission in the range of 300-450 nm was recorded. The light scattering values at $350 \mathrm{~nm}$ were then plotted against $\mathrm{C}_{16} \mathrm{C}_{4} \mathrm{C}_{16} \mathrm{Br}_{2}$ concentration.

\section{Tryptophan fluorescence}

Trp fluorescence spectra were scanned on a Cary Eclipse fluorescence spectrophotometer in a $1 \mathrm{~cm}$ path-length quartz cell. All the samples BLC $\left(0.2 \mathrm{mg} \mathrm{mL}^{-1}\right)$ with and without $\mathrm{C}_{16} \mathrm{C}_{4} \mathrm{C}_{16} \mathrm{Br}_{2}$ were equilibrated for $12 \mathrm{~h}$ at room temperature. $\mathrm{A}$ BLC concentration of $0.2 \mathrm{mg} \mathrm{mL}^{-1}$ was used in all the samples and the measurements were made at room temperature. All the samples were excited at $295 \mathrm{~nm}$ and the spectra were scanned in from 300 to $400 \mathrm{~nm}$.

\section{Thioflavin-T (ThT) assay}

ThT was dissolved in MilliQ water and filtered through a 0.45 $\mu \mathrm{M}$ Millipore syringe filter. After filtration, the ThT concentration was calculated using a molar extinction coefficient of $36000 \mathrm{M}^{-1} \mathrm{~cm}^{-1}$ at $412 \mathrm{~nm}$. The BLC samples $\left(0.2 \mathrm{mg} \mathrm{mL}^{-1}\right)$ treated with different $\mathrm{C}_{16} \mathrm{C}_{4} \mathrm{C}_{16} \mathrm{Br}_{2}$ concentrations were incubated for $12 \mathrm{~h}$ at $\mathrm{pH}$ 7.4. The 5.0 $\mu \mathrm{M}$ ThT solution was added to the $\mathrm{C}_{16} \mathrm{C}_{4} \mathrm{C}_{16} \mathrm{Br}_{2}$-treated $\mathrm{BLC}$ samples and again incubate for $30 \mathrm{~min}$ in the dark. ThT-incubated samples were then excited at $440 \mathrm{~nm}$ and emission was recorded from 450 to $600 \mathrm{~nm}$ on a Cary Eclipse fluorescence spectrophotometer. Excitation and emission slit widths were fixed at $5.0 \mathrm{~nm}$.

\section{Circular dichroism measurements}

CD measurements were made at room temperature on a Chirascan Plus spectropolarimeter (Applied Photophysics Ltd., Leatherhead, Surrey, UK) was calibrated with ammonium 
(+)-10-camphorsulfonate. The CD results are presented as the mean residual ellipticity (MRE).

$$
\mathrm{MRE}=\theta_{\mathrm{obs}}(\mathrm{mdeg}) / 10 \times n \times C_{\mathrm{p}} \times 1
$$

where $\theta_{\mathrm{obs}}$ is the CD in millidegrees, $n$ is the number of amino acids, $C_{\mathrm{p}}$ is the concentration in molar fraction and $l$ is the path length in $\mathrm{mm}$. The CD spectra of BLC $\left(0.2 \mathrm{mg} \mathrm{mL}^{-1}\right)$ treated with or without $\mathrm{C}_{16} \mathrm{C}_{4} \mathrm{C}_{16} \mathrm{Br}_{2}$ were measured in a $1 \mathrm{~mm}$ quartz cell at room temperature. Percent secondary structure was calculated by using the K2D2 method.

\section{Transmission electron microscopy (TEM)}

TEM images of $\mathrm{C}_{16} \mathrm{C}_{4} \mathrm{C}_{16} \mathrm{Br}_{2}$-induced BLC aggregates were viewed on a JOEL TEM operating at an accelerating voltage of $200 \mathrm{kV}$. The $10 \mu \mathrm{L}$ samples of $\mathrm{C}_{16} \mathrm{C}_{4} \mathrm{C}_{16} \mathrm{Br}_{2}$-induced BLC aggregate were poured onto a 200-mesh copper grid and incubated for $5 \mathrm{~min}$. The excess fluids were removed using Whatman paper and then the dried grids were negatively stained with $2 \%$ $(\mathrm{w} / \mathrm{v})$ uranyl acetate. The stained grids were further dried in a desiccator for two days and then viewed in TEM.

\section{Molecular docking}

To visualize the interaction between $\mathrm{C}_{16} \mathrm{C}_{4} \mathrm{C}_{16} \mathrm{Br}_{2}$ and BLC, molecular docking was performed using AutoDock4.2 as described previously. ${ }^{31}$ The $2 \mathrm{D}$ structure of $\mathrm{C}_{16} \mathrm{C}_{4} \mathrm{C}_{16} \mathrm{Br}_{2}$ was drawn using the Sketcher module in "Maestro-2018 (Schrodinger, LLC, NY, USA)" and its energy was minimized using the OPLS3e forcefield. The ionization state of $\mathrm{C}_{16} \mathrm{C}_{4} \mathrm{C}_{16} \mathrm{Br}_{2}$ was generated at $\mathrm{pH} 7.4$ using Epik-2018 (Schrodinger, LLC, NY, USA). The 3D coordinates of BLC (PDB ID 1TGU) were retrieved from PDB-RCSB databank. Before molecular docking, the BLC structure was preprocessed using the protein preparation wizard of Maestro-2018 (Schrodinger, LLC, NY, USA) as reported previously. ${ }^{32}$ Crystallographic water molecules and any heterogeneous ligand were deleted, missing hydrogen atoms were incorporated, and correct bond orders were allotted. A network of hydrogen bonds was produced and the whole system was energy-minimized using the OPLS3e forcefield. The dimensions of the grid-box were set to $85 \times 85 \times 85 \AA$ centered at $36.3,32.1$, and $29.0 \AA$ with $0.375 \AA$ spacing. For molecular docking, Lamarckian Genetic Algorithm (LGA) along with Solis and Wets local search methods were engaged, as described previously. ${ }^{33}$ The initial position of $\mathrm{C}_{16} \mathrm{C}_{4} \mathrm{C}_{16} \mathrm{Br}_{2}$, its orientation and torsion were set arbitrarily. The maximum number of energy calculations was set at $2.5 \times 10^{6}$ for each docking run, keeping the population size at 150 , the translational step at $0.2 \AA$, and torsion steps and quaternion at 5. Discovery Studio (Accelrys) was utilized to analyze the docking results and prepare the final figures. The docking affinity of $\mathrm{C}_{16} \mathrm{C}_{4} \mathrm{C}_{16} \mathrm{Br}_{2}$ for BLC was determined from docking energy $(\Delta G)$ using the following equation: ${ }^{34}$

$$
\Delta G=-R T \ln K_{\mathrm{d}}
$$

where $R$ is the Boltzmann gas constant and $T$ is the temperature.

\section{Molecular dynamics simulation}

$\mathrm{C}_{16} \mathrm{C}_{4} \mathrm{C}_{16} \mathrm{Br}_{2}$ was evaluated by performing a molecular dynamics simulation using Desmond-2018 (Schrodinger, LLC, NY, USA) as reported previously. ${ }^{31}$ Briefly, the BLC- $\mathrm{C}_{16} \mathrm{C}_{4} \mathrm{C}_{16} \mathrm{Br}_{2}$ complex was placed at the center of an orthorhombic simulation box, and at least $1 \mathrm{~nm}$ away from the box boundaries. The simulation box was solvated with TIP3P water molecules and counterions were added to neutralize the system. Physiological conditions were mimicked by adding $150 \mathrm{mM} \mathrm{NaCl}$. The temperature and pressure were maintained at $300 \mathrm{~K}$ and 1 bar atmosphere and maintained constant throughout the simulation using NoseHoover chain thermostat and Martyna-Tobias-Klein barostat, respectively. ${ }^{9,35}$ Before the production run, the whole system was minimized (2000 iterations) keeping a convergence criterion of

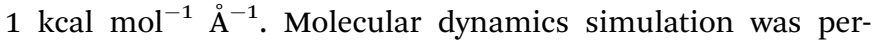
formed for $50 \mathrm{~ns}$ with a time step of $2 \mathrm{fs}$. The structure and energy were recorded in the trajectory at every $10 \mathrm{ps}$. The results were analyzed in Maestro-2018 (Schrodinger, LLC, NY, USA) and the plots were drawn in Origin Pro 8.

\section{Evaluation of the cytotoxic effect of the gemini surfactant}

The cytotoxic activity of $\mathrm{C}_{16} \mathrm{C}_{4} \mathrm{C}_{16} \mathrm{Br}_{2}$ was tested in a human lung cancer cell line A549 (ATCC® CCL-185) which was obtained from ATCC. Briefly, the A549 cells were seeded in a 96-well plate $\left(1 \times 10^{4}\right.$ cells per well) and kept overnight for adhesion at $37^{\circ} \mathrm{C}$ in a humidified atmosphere at $5 \% \mathrm{CO}_{2}$. The culture was maintained in Dulbecco's Modified Eagle Medium (DMEM) (GIBCO) supplemented with 10\% Fetal Bovine Serum (FBS) and $1 \%$ penicillin-streptomycin antibiotic $\left(10000 \mathrm{U} \mathrm{ml}^{-1}\right)$. The next day cells were washed twice with $1 \times$ PBS and placed in fresh medium (DMEM without FBS and antibiotic) along with different concentrations of $\mathrm{C}_{16} \mathrm{C}_{4} \mathrm{C}_{16} \mathrm{Br}_{2}(0 \mu \mathrm{M}$ to $100 \mu \mathrm{M})$ and incubated for $3.5 \mathrm{~h}$ at $37{ }^{\circ} \mathrm{C}$. Controls with and without $\mathrm{C}_{16} \mathrm{C}_{4} \mathrm{C}_{16} \mathrm{Br}_{2}$ were set aside to determine the extent of cell survival. After $3.5 \mathrm{~h}$, the cellular morphology changes were observed using a phase-contrast microscope. MTT $(10 \mu \mathrm{L}$ at $10 \mathrm{mg}$ $\mathrm{mL}^{-1}$ ) was added in each well and incubated for 3 hours at $37^{\circ} \mathrm{C}$. Living cells reduce the yellow dye MTT to purple formazan. After removal of medium, $200 \mu \mathrm{L}$ of acidified isopropyl alcohol $(0.04 \mathrm{~N}$ $\mathrm{HCl})$ was added and the samples were slowly shaken at room temperature for 10 to $15 \mathrm{~min}$. The color change was quantified with an ELISA plate reader $(570 \mathrm{~nm})$ using a Bio-Tek microplate reader. The cell viability was calculated as follows:

$$
\% V=\left(A_{\text {treatment }}-A_{\text {blank }} / A_{\text {control }}-A_{\text {blank }}\right) \times 100
$$

where $V$ is the viability of cells, $A$ is the absorbance of the cells.

\section{Results}

\section{Rayleigh scattering measurements}

The fluorescence intensity at $350 \mathrm{~nm}$ after excitation at the same wavelength is a very sensitive method used to study protein aggregation. The RLS measurements allowed us to observe the impact of $\mathrm{C}_{16} \mathrm{C}_{4} \mathrm{C}_{16} \mathrm{Br}_{2}$ on BLC aggregation at $\mathrm{pH}$ 7.4. The light scattering at $350 \mathrm{~nm}$ of BLC samples with increasing concentrations of 


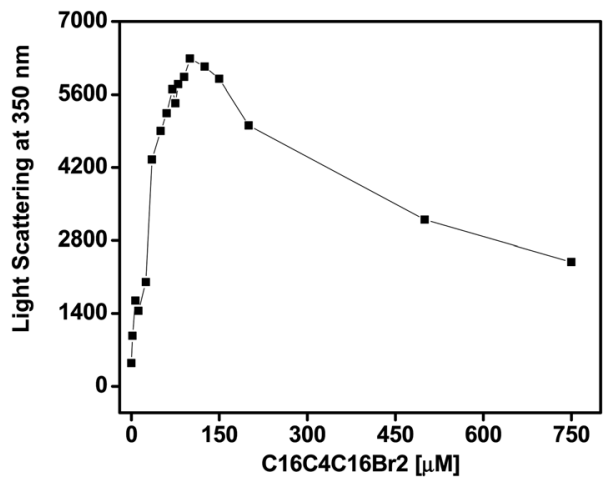

Fig. 1 Light scattering profile of $B L C$ in the presence of $C_{16} C_{4} C_{16} B r_{2}$ at $\mathrm{pH} 7.4$.

$\mathrm{C}_{16} \mathrm{C}_{4} \mathrm{C}_{16} \mathrm{Br}_{2}$ was measured at $\mathrm{pH} 7.4$ at room temperature. As shown in Fig. 1, the BLC sample without $\mathrm{C}_{16} \mathrm{C}_{4} \mathrm{C}_{16} \mathrm{Br}_{2}$ showed no scattering, indicating the absence of aggregates at this $\mathrm{pH}$. However, the for BLC samples incubated with $\mathrm{C}_{16} \mathrm{C}_{4} \mathrm{C}_{16} \mathrm{Br}_{2}$ concentrations from 2.0 to $125.0 \mu \mathrm{M}$, a continuous increase in light scattering was recorded. Moreover, for concentrations $\geq 150.0 \mu \mathrm{M}$ scattering suddenly dropped but was not completely lost. The RLS results suggest that at $\mathrm{C}_{16} \mathrm{C}_{4} \mathrm{C}_{16} \mathrm{Br}_{2}$ concentrations ranging from 35.0 to $125.0 \mu \mathrm{M}$, large aggregates were formed, and the scattering drop observed at higher $\mathrm{C}_{16} \mathrm{C}_{4} \mathrm{C}_{16} \mathrm{Br}_{2}$ concentrations was due to the formation of smaller BLC aggregates.

\section{Intrinsic fluorescence changes of $\mathrm{BLC}$ exposed to $\mathrm{C}_{16} \mathrm{C}_{4} \mathrm{C}_{16} \mathrm{Br}_{2}$}

Most proteins possess tryptophan (Trp), tyrosine (Tyr), and phenylalanine (Phe) amino acids and these residues have an intrinsic fluorescence property. Intrinsic fluorescence spectroscopy is an effective method to evaluate the conformational changes of BLC caused by $\mathrm{C}_{16} \mathrm{C}_{4} \mathrm{C}_{16} \mathrm{Br}_{2}$. The BLC samples with increasing concentrations of $\mathrm{C}_{16} \mathrm{C}_{4} \mathrm{C}_{16} \mathrm{Br}_{2}$ were excited at $295 \mathrm{~nm}$ which exclusively excites the Trp residues and the emission maximum between 300 and $400 \mathrm{~nm}$ was recorded. As shown in Fig. 2, the emission maximum of BLC was observed at $\sim 335 \mathrm{~nm}$. However, the fluorescence intensity of BLC decreases after the addition of

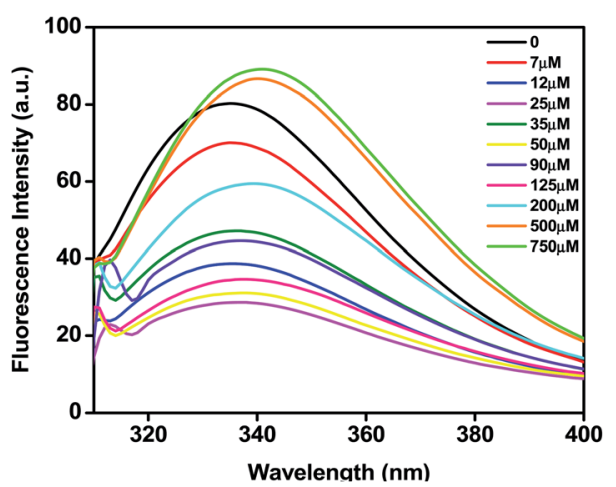

Fig. 2 Trp fluorescence spectra of BLC $\left(0.2 \mathrm{mg} \mathrm{mL}^{-1}\right)$ in the absence (-) and presence of $7(-), 12(-), 25(-), 35(-), 50(-), 90(-), 125(-)$, 200(-), 500(-) and $750(-) \mu \mathrm{M}$ of $\mathrm{C}_{16} \mathrm{C}_{4} \mathrm{C}_{16} \mathrm{Br}_{2}$ in $20 \mathrm{mM}$ phosphate buffer at $\mathrm{pH} 7.4$.
$\mathrm{C}_{16} \mathrm{C}_{4} \mathrm{C}_{16} \mathrm{Br}_{2}$ (7-125 $\left.\mu \mathrm{M}\right)$ and the wavelength maximum was significantly shifted towards red wavelength. The initial decrease in fluorescence intensity with a slight red shift in wavelength maxima indicates that BLC forms aggregates in the presence of $\mathrm{C}_{16} \mathrm{C}_{4} \mathrm{C}_{16} \mathrm{Br}_{2}$. Next, the fluorescence intensity of BLC increased compared to native $\mathrm{BLC}$ with a red shift of almost $10 \mathrm{~nm}$ in the presence of higher $\mathrm{C}_{16} \mathrm{C}_{4} \mathrm{C}_{16} \mathrm{Br}_{2}$ concentrations (500.0 and 750.0 $\mu \mathrm{M})$. This increase in fluorescence intensity accompanied by a red shift was characteristic of a conformational change of BLC. The change in intrinsic fluorescence suggests that BLC aggregates in the presence of lower $\mathrm{C}_{16} \mathrm{C}_{4} \mathrm{C}_{16} \mathrm{Br}_{2}$ concentrations, while higher concentrations provoke conformational changes.

\section{Gemini $\left(\mathrm{C}_{16} \mathrm{C}_{4} \mathrm{C}_{16} \mathrm{Br}_{2}\right)$-induced fibrillation of $\mathrm{BLC}$ measured by ThT}

We assessed the influence of $\mathrm{C}_{16} \mathrm{C}_{4} \mathrm{C}_{16} \mathrm{Br}_{2}$ on the fibrillation of BLC using a ThT fluorescence assay. ThT dye binding is a widely used method to monitor the fibrillation of proteins. As shown in Fig. 3, the BLC sample without $\mathrm{C}_{16} \mathrm{C}_{4} \mathrm{C}_{16} \mathrm{Br}_{2}$ does not display ThT fluorescence, which confirms that BLC alone does not aggregate. When lower concentrations $(12-90 \mu \mathrm{M})$ of $\mathrm{C}_{16} \mathrm{C}_{4} \mathrm{C}_{16} \mathrm{Br}_{2}$ were added, the ThT fluorescence increased dose-dependently, reaching a maximum value at $90 \mu \mathrm{M} \mathrm{C}_{16} \mathrm{C}_{4} \mathrm{C}_{16} \mathrm{Br}_{2}$. In contrast, higher concentrations of $\mathrm{C}_{16} \mathrm{C}_{4} \mathrm{C}_{16} \mathrm{Br}_{2}(\geq 150 \mu \mathrm{M})$ resulted in a complete loss of ThT fluorescence. Overall, these results suggest that low concentrations of $\mathrm{C}_{16} \mathrm{C}_{4} \mathrm{C}_{16} \mathrm{Br}_{2}$ dose-dependently induce amyloid fibrillation of BLC but the fibrils disappeared in the presence of higher $\mathrm{C}_{16} \mathrm{C}_{4} \mathrm{C}_{16} \mathrm{Br}_{2}$ concentrations.

\section{Secondary structure modification by $\mathrm{C}_{16} \mathrm{C}_{4} \mathrm{C}_{16} \mathrm{Br}_{2}$}

The effect of $\mathrm{C}_{16} \mathrm{C}_{4} \mathrm{C}_{16} \mathrm{Br}_{2}$ on the secondary structure of BLC was studied by $\mathrm{CD}$ spectroscopy. As presented in Fig. 4, the far UVCD spectrum of BLC without $\mathrm{C}_{16} \mathrm{C}_{4} \mathrm{C}_{16} \mathrm{Br}_{2}$ shows two negative minima around 208 and $222 \mathrm{~nm}$, which is typical of $\alpha$-helical structure. ${ }^{36}$ When BLC was treated with 12.0-90.0 $\mu \mathrm{M}$ of $\mathrm{C}_{16} \mathrm{C}_{4} \mathrm{C}_{16} \mathrm{Br}_{2}$, negative ellipticity decreased gradually, reaching a minimum in the presence of $90.0 \mu \mathrm{M} \mathrm{C}{ }_{16} \mathrm{C}_{4} \mathrm{C}_{16} \mathrm{Br}_{2}$. These changes in negative ellipticity indicate a reduction of $\alpha$-helix

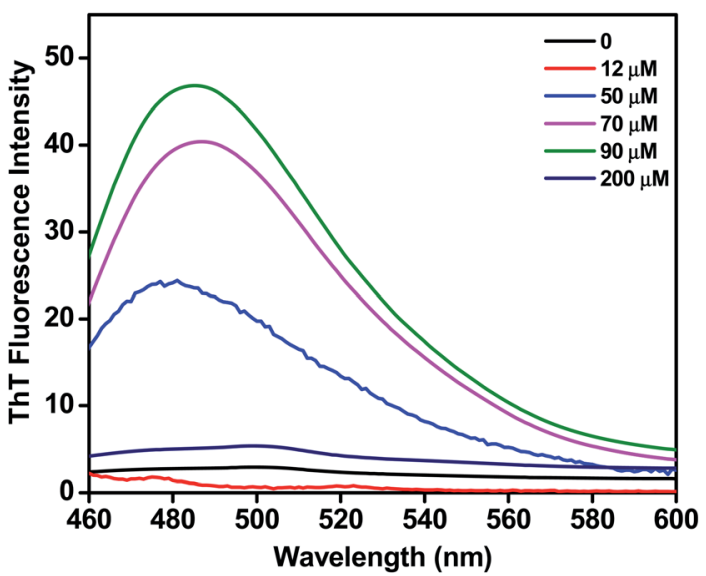

Fig. 3 ThT fluorescence spectra of BLC $\left(0.2 \mathrm{mg} \mathrm{mL}^{-1}\right)$ without and with $\mathrm{C}_{16} \mathrm{C}_{4} \mathrm{C}_{16} \mathrm{Br}_{2}$ at $\mathrm{pH} 7.4$. 




Fig. 4 Far-UV CD spectra of BLC with different concentrations $\mathrm{C}_{16} \mathrm{C}_{4} \mathrm{C}_{16} \mathrm{Br}_{2}$ surfactant at $\mathrm{pH} 7.4$.

due to BLC aggregation. However, in presence of 200.0-750.0 $\mu \mathrm{M} \mathrm{C}_{16} \mathrm{C}_{4} \mathrm{C}_{16} \mathrm{Br}_{2}$, the BLC regained negative ellipticity, which reached a maximum in the presence of $750.0 \mu \mathrm{M} \mathrm{C}_{16} \mathrm{C}_{4} \mathrm{C}_{16} \mathrm{Br}_{2}$. The structural content of $\mathrm{BLC}$ in response to $\mathrm{C}_{16} \mathrm{C}_{4} \mathrm{C}_{16} \mathrm{Br}_{2}$ surfactant was calculated using the $\mathrm{K} 2 \mathrm{D} 2$ method and the data are presented in Table 1 . Overall, the far-UV CD results suggest that low concentrations of $\mathrm{C}_{16} \mathrm{C}_{4} \mathrm{C}_{16} \mathrm{Br}_{2}$ stimulate the aggregation of BLC and reduce $\alpha$-helicity, while higher concentrations of $\mathrm{C}_{16} \mathrm{C}_{4} \mathrm{C}_{16} \mathrm{Br}_{2}$ provoked a regain in $\alpha$-helicity.

\section{Fibril morphology investigated by TEM}

The imaging techniques was used to verify our spectroscopic results, the morphology of $\mathrm{C}_{16} \mathrm{C}_{4} \mathrm{C}_{16} \mathrm{Br}_{2}$-induced BLC aggregates was examined by TEM microscopy. The electron microscopy images of $\mathrm{BLC}$ without and with $\mathrm{C}_{16} \mathrm{C}_{4} \mathrm{C}_{16} \mathrm{Br}_{2}$ are reported in Fig. 5. BLC without $\mathrm{C}_{16} \mathrm{C}_{4} \mathrm{C}_{16} \mathrm{Br}_{2}$ displayed no fibril structure. However, BLC with $90.0 \mu \mathrm{M} \mathrm{C}_{16} \mathrm{C}_{4} \mathrm{C}_{16} \mathrm{Br}_{2}$ showed a typical long unbranched amyloid fibrils structure. The TEM images confirm that BLC forms a well-defined amyloid-like structure.

\section{Analysis of molecular docking between $\mathrm{BLC}$ and $\mathrm{C}_{16} \mathrm{C}_{4} \mathrm{C}_{16} \mathrm{Br}_{2}$ surfactant}

BLC is a dumbbell-shaped tetramer of identical monomers comprised of 506 amino acid residues, and contains a heme

Table 1 Secondary structure content of BLC without and with different concentrations of $\mathrm{C}_{16} \mathrm{C}_{4} \mathrm{C}_{16} \mathrm{Br}_{2}$

\begin{tabular}{llrl}
\hline S. no. & Conditions & $\% \alpha$-helix & $\% \beta$-sheet \\
\hline 1 & $\mathrm{BLC}$ & $38.04 \pm 1.00$ & $10.06 \pm 1.02$ \\
2 & $\mathrm{BLC}+12.0 \mu \mathrm{M} \mathrm{C}_{16} \mathrm{C}_{4} \mathrm{C}_{16} \mathrm{Br}_{2}$ & $38.04 \pm 1.06$ & $10.06 \pm 1.03$ \\
3 & $\mathrm{BLC}+25.0 \mu \mathrm{M} \mathrm{C}_{16} \mathrm{C}_{4} \mathrm{C}_{16} \mathrm{Br}_{2}$ & $36.00 \pm 1.16$ & $15.29 \pm 1.04$ \\
4 & $\mathrm{BLC}+35.0 \mu \mathrm{M} \mathrm{C}_{16} \mathrm{C}_{4} \mathrm{C}_{16} \mathrm{Br}_{2}$ & $35.93 \pm 1.01$ & $12.19 \pm 1.02$ \\
5 & $\mathrm{BLC}+50.0 \mu \mathrm{M} \mathrm{C}_{16} \mathrm{C}_{4} \mathrm{C}_{16} \mathrm{Br}_{2}$ & $15.83 \pm 1.15$ & $31.46 \pm 1.00$ \\
6 & $\mathrm{BLC}+70.0 \mu \mathrm{M} \mathrm{C}_{16} \mathrm{C}_{4} \mathrm{C}_{16} \mathrm{Br}_{2}$ & $14.47 \pm 1.09$ & $35.07 \pm 1.07$ \\
7 & $\mathrm{BLC}+90.0 \mu \mathrm{M} \mathrm{C}_{16} \mathrm{C}_{4} \mathrm{C}_{16} \mathrm{Br}_{2}$ & $7.98 \pm 1.40$ & $58.94 \pm 1.23$ \\
8 & $\mathrm{BLC}+200.0 \mu \mathrm{M} \mathrm{C}_{16} \mathrm{C}_{4} \mathrm{C}_{16} \mathrm{Br}_{2}$ & $30.60 \pm 1.50$ & $12.77 \pm 1.25$ \\
9 & $\mathrm{BLC}+500.0 \mu \mathrm{M} \mathrm{C}_{16} \mathrm{C}_{4} \mathrm{C}_{16} \mathrm{Br}_{2}$ & $35.86 \pm 1.43$ & $11.33 \pm 1.72$ \\
10 & $\mathrm{BLC}+750.0 \mu \mathrm{M} \mathrm{C}_{16} \mathrm{C}_{4} \mathrm{C}_{16} \mathrm{Br}_{2}$ & $37.33 \pm 1.85$ & $10.06 \pm 1.65$
\end{tabular}

and NADH binding sites. ${ }^{37}$ Each monomer is composed of four domains I-IV spanning through amino acid residues 1-75, 76320, 321-436 and 437-506 respectively. ${ }^{38}$ The heme moiety of BLC is located in domain II, which is also the largest domain of BLC. Notably, the surface of BLC is composed of domain IV along with three $\alpha$-helices of the heme-containing domain II. $^{39,40}$ In this study, the analysis of molecular docking between $\mathrm{C}_{16} \mathrm{C}_{4} \mathrm{C}_{16} \mathrm{Br}_{2}$ and BLC suggested that $\mathrm{C}_{16} \mathrm{C}_{4} \mathrm{C}_{16} \mathrm{Br}_{2}$ bound to domain II but away from the heme and NADPH binding sites (Fig. 6 and Table 2). Primarily, $\mathrm{C}_{16} \mathrm{C}_{4} \mathrm{C}_{16} \mathrm{Br}_{2}$ interacts with BLC through electrostatic interactions (attractive type with Asp127 and Pi-cation type with His465), carbon-hydrogen bonding (Arg126, Asp127, and Gln167), and hydrophobic interaction (alkyl type with Val125). In addition, BLC and $\mathrm{C}_{16} \mathrm{C}_{4} \mathrm{C}_{16} \mathrm{Br}_{2}$ formed many van der Waals' interactions with residues Ser121, Ala122, Thr124, Lys176, Pro178, Trp185, Phe199, Val246, Ala249, Ala250, Ala253, and Asn461 (Fig. 7 and Table 2). The docking energy and the corresponding docking affinity of $\mathrm{C}_{16} \mathrm{C}_{4} \mathrm{C}_{16} \mathrm{Br}_{2}$ towards BLC were predicted to be $-5.5 \mathrm{kcal} \mathrm{mol}^{-1}$ and $1.08 \times 10^{4} \mathrm{M}^{-1}$ respectively (Table 2 ).

\section{Analysis of molecular dynamics simulation}

The stability and dynamics of $\mathrm{BLC}-\mathrm{C}_{16} \mathrm{C}_{4} \mathrm{C}_{16} \mathrm{Br}_{2}$ complex were evaluated by performing molecular dynamics simulation for 50 ns (Fig. 7). Root mean square deviation (RMSD) is a measure of deviation in the structure of the protein-ligand complex from the initial from, throughout the simulation. Here, we have determined the RMSD across C $\alpha$-atoms of BLC in the absence and presence of $\mathrm{C}_{16} \mathrm{C}_{4} \mathrm{C}_{16} \mathrm{Br}_{2}$. In Fig. 7A, it is apparent that the RMSD of BLC alone initially, and stabilizes after $30 \mathrm{~ns}$ of simulation. Conversely, the RMSD of $\mathrm{BLC}$ and $\mathrm{C}_{16} \mathrm{C}_{4} \mathrm{C}_{16} \mathrm{Br}_{2}$ complex remains constant during $10-50$ ns of simulation time, thereby indicating the formation of a stable complex. The average RMSD values of BLC in the absence and presence of $\mathrm{C}_{16} \mathrm{C}_{4} \mathrm{C}_{16} \mathrm{Br}_{2}$ were estimated to be 0.66 and $0.55 \mathrm{~nm}$, respectively, which are within the acceptable limit of $0.2 \mathrm{~nm}$.

Root mean square fluctuation (RMSF) is a measure of protein's flexibility due to the movement of the protein's side chains. Here, we estimated the flexibility and rigidity of BLC's amino acid residues in the absence and presence of $\mathrm{C}_{16} \mathrm{C}_{4} \mathrm{C}_{16} \mathrm{Br}_{2}$ by measuring the RMSF of $\mathrm{C} \alpha$-atoms during $50 \mathrm{~ns}$ simulation. As shown in Fig. 7B, the average RMSF values of BLC and the BLC- $\mathrm{C}_{16} \mathrm{C}_{4} \mathrm{C}_{16} \mathrm{Br}_{2}$ complex were 0.18 and $0.27 \mathrm{~nm}$ respectively. The most fluctuating regions of native BLC protein and BLC$\mathrm{C}_{16} \mathrm{C}_{4} \mathrm{C}_{16} \mathrm{Br}_{2}$ complex are two loop regions present at the $\mathrm{N}$ - and C-terminal ends (residues 19-25 and 366-439 respectively). Overall, these results indicate that $\mathrm{C}_{16} \mathrm{C}_{4} \mathrm{C}_{16} \mathrm{Br}_{2}$ forms a stable complex with BLC.

The radius of gyration $\left(R_{\mathrm{g}}\right)$ measures the overall compactness of a protein upon ligand binding and during the simulation. Analyses of $R_{\mathrm{g}}$ also reveal the folding pattern, stability, and conformational changes in protein due to ligand binding. Here, we monitored the $R_{\mathrm{g}}$ of $\mathrm{BLC}$ and the $\mathrm{BLC}-\mathrm{C}_{16} \mathrm{C}_{4} \mathrm{C}_{16} \mathrm{Br}_{2}$ complex as a function of simulation time (Fig. 7C). The average $R_{\mathrm{g}}$ values of $\mathrm{BLC}$ alone or in complex with $\mathrm{C}_{16} \mathrm{C}_{4} \mathrm{C}_{16} \mathrm{Br}_{2}$ were estimated to be 2.51 and $2.62 \mathrm{~nm}$, respectively. A slight increase in the $R_{\mathrm{g}}$ of 

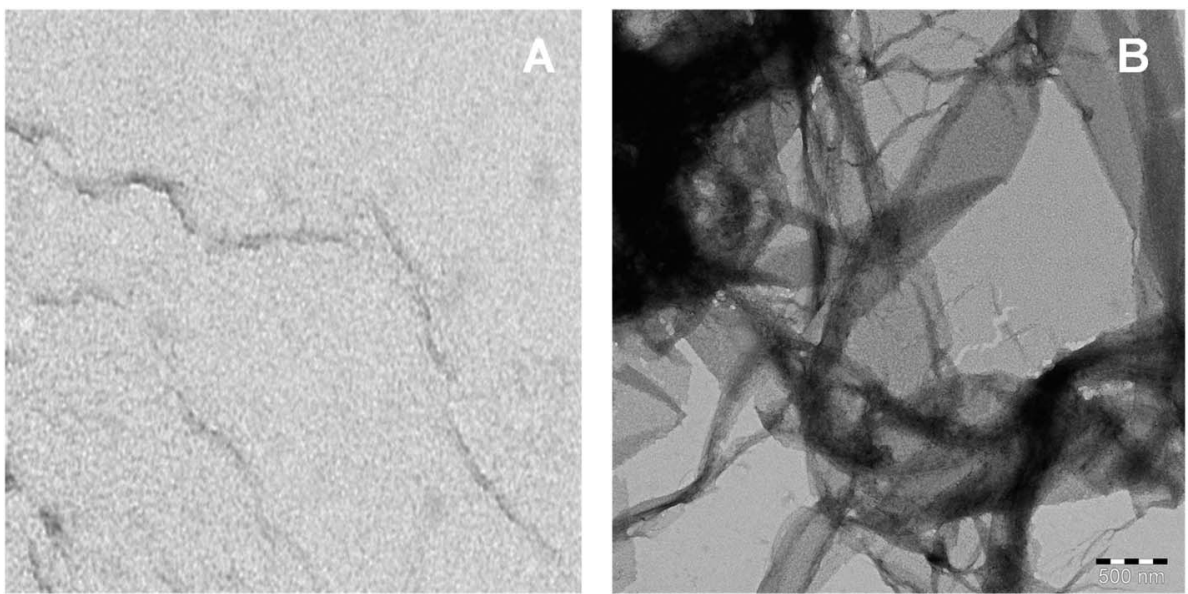

Fig. 5 TEM image of native BLC and BLC fibril in the presence of $90.0 \mu \mathrm{M}$ of $\mathrm{C}_{16} \mathrm{C}_{4} \mathrm{C}_{16} \mathrm{Br}_{2}$ at $\mathrm{pH}$ 7.4.

the BLC- $\mathrm{C}_{16} \mathrm{C}_{4} \mathrm{C}_{16} \mathrm{Br}_{2}$ complex indicates that the binding of $\mathrm{C}_{16} \mathrm{C}_{4} \mathrm{C}_{16} \mathrm{Br}_{2}$ resulted in a partial loss of BLC compactness measures the exposure of amino acid residues to the solvent as a result of ligand binding. Here, we monitored the SASA of BLC alone or the BLC- $\mathrm{C}_{16} \mathrm{C}_{4} \mathrm{C}_{16} \mathrm{Br}_{2}$ complex throughout simulation time (Fig. 7D). We found that the SASA of BLC and the BLC$\mathrm{C}_{16} \mathrm{C}_{4} \mathrm{C}_{16} \mathrm{Br}_{2}$ complex remained constant throughout the simulation, with average values of 265.4 and $299.66 \mathrm{~nm}^{2}$, respectively. A slight increase in the SASA of $\mathrm{C}_{16} \mathrm{C}_{4} \mathrm{C}_{16} \mathrm{Br}_{2}$-bound BLC indicates that the protein is partially exposed to the surrounding solvent molecules.

\section{Cytotoxicity results}

$\mathrm{C}_{16} \mathrm{C}_{4} \mathrm{C}_{16} \mathrm{Br}_{2}$ was performed on A549 cells using an MTT assay. The histogram of cell survival versus the different concentrations of $\mathrm{C}_{16} \mathrm{C}_{4} \mathrm{C}_{16} \mathrm{Br}_{2}$ is presented in Fig. 8A.



Fig. 6 Interaction between $\mathrm{BLC}$ and $\mathrm{C}_{16} \mathrm{C}_{4} \mathrm{C}_{16} \mathrm{Br}_{2}$ through molecular docking. (A) Ribbon structure of $\mathrm{BLC}$ binding to $\mathrm{C}_{16} \mathrm{C}_{4} \mathrm{C}_{16} \mathrm{Br}_{2}$, $(\mathrm{B})$ binding of $\mathrm{C}_{16} \mathrm{C}_{4} \mathrm{C}_{16} \mathrm{Br}_{2}$ at the hydrophobic cavity of $\mathrm{BLC}$ located in domain II, and (C) amino acid residues and types of interactions involved in $\mathrm{BLC}$ and $\mathrm{C}_{16} \mathrm{C}_{4} \mathrm{C}_{16} \mathrm{Br}_{2}$ binding. Electrostatic interactions are represented in red, hydrophobic interaction teal, and carbon-hydrogen bonds in green. 
Table 2 Interaction parameters between $\mathrm{BLC}$ and $\mathrm{C}_{16} \mathrm{C}_{4} \mathrm{C}_{16} \mathrm{Br}_{2}$ as deduced by molecular docking



The strong cytotoxicity of $\mathrm{C}_{16} \mathrm{C}_{4} \mathrm{C}_{16} \mathrm{Br}_{2}$ against $\mathrm{A} 549$ cells was observed from the concentration of $10 \mu \mathrm{M}$ and most of the cell is died and morphology is changed within $3.5 \mathrm{~h}$ of incubation at $37^{\circ} \mathrm{C}$ shown in Fig. 8A and B. However, the cells were remained healthy and survived in the presence of low concentrations (1-3 $\mu \mathrm{M})$ of $\mathrm{C}_{16} \mathrm{C}_{4} \mathrm{C}_{16} \mathrm{Br}_{2}$ and the morphology of cell is unchanged. The non-polar and polar parts of the surfactant interact with the lipid bilayer and form holes in the cell surface, which leads to the leakage of cytoplasmic constituents and eventually to cell destruction. ${ }^{\mathbf{4 1 - 4 3}}$

\section{Discussion}

Surfactants generally interact with proteins through electrostatic and hydrophobic interactions and cause conformational changes which can result in protein aggregation and
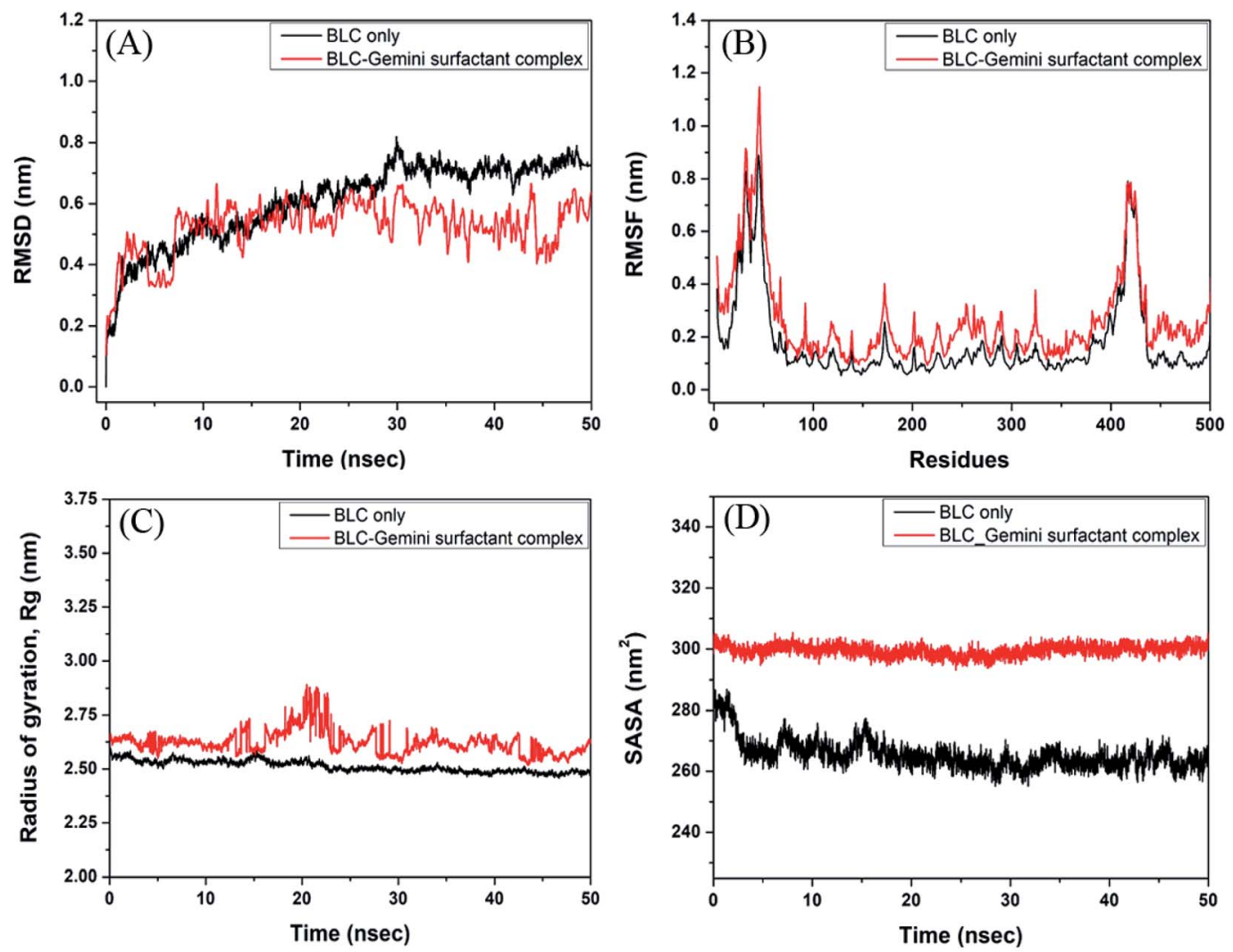

Fig. 7 Molecular dynamics simulation of $\mathrm{BLC}-\mathrm{C}_{16} \mathrm{C}_{4} \mathrm{C}_{16} \mathrm{Br}_{2}$ complex. (A) Root mean square deviation (RMSD), (B) root mean square fluctuation (RMSD), (C) radius of gyration $\left(R_{\mathrm{g}}\right)$, and (D) solvent accessible surface area (SASA) of BLC C $\alpha$-atoms in the absence and presence of $\mathrm{C}_{16} \mathrm{C}_{4} \mathrm{C}_{16} \mathrm{Br}_{2}$. 


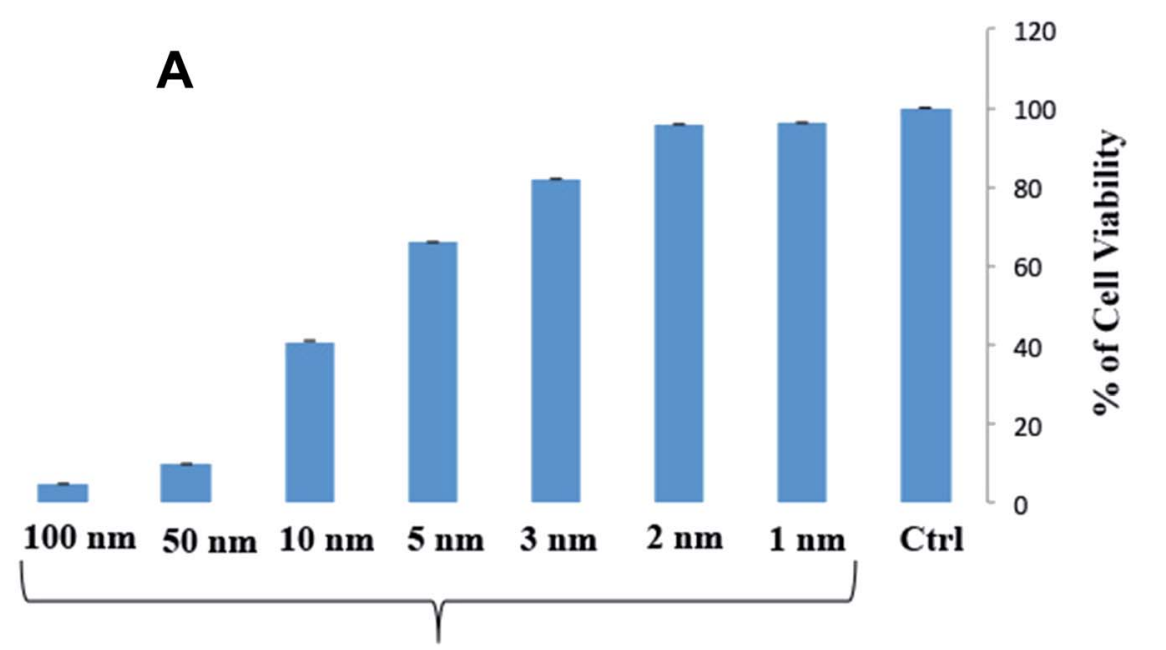

\section{Gemini With Different concentration}

\section{B}

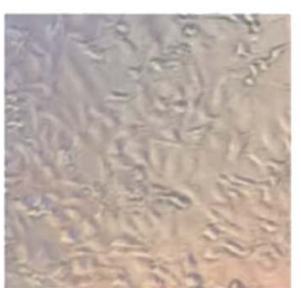

Control

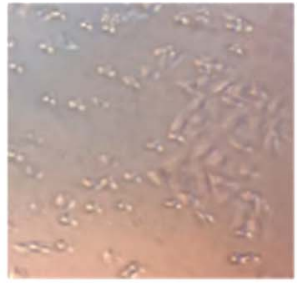

5 uM

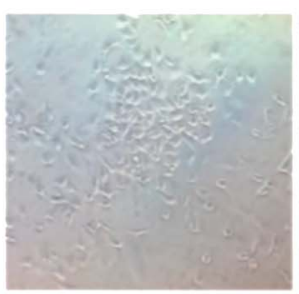

$1 \mathrm{uM}$

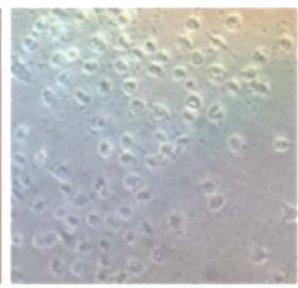

10 uM

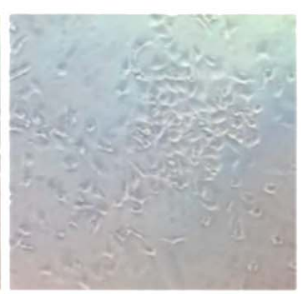

$2 \mathrm{uM}$



50 uM

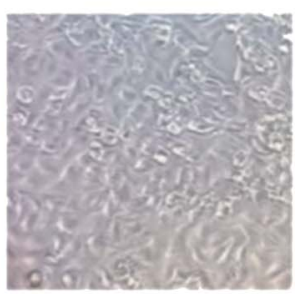

$3 \mathrm{uM}$

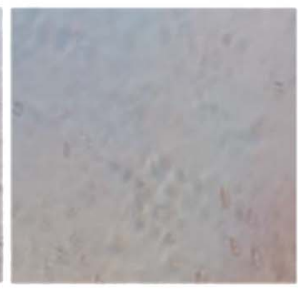

$100 \mathrm{uM}$

Fig. 8 (A) Cell viability assay: histogram showing the mean absorbance value obtained from the MTT assay in A549 cells after treatment with different concentration $(0 \mu \mathrm{M}$ to $100 \mu \mathrm{M})$ for $3.5 \mathrm{~h}$. The error bars indicate the standard error calculated from two independent experiments in duplicate. (B) Phase-contrast images of morphological changes observed in $A 549$ cells after exposure of different concentrations of $C_{16} C_{4} C_{16} B r_{2}$ surfactant for $3.5 \mathrm{~h}$.

unfolding. ${ }^{44}$ Common surfactants such as SDS, cetyltrimethylammonium bromide (CTAB), and TX-100 stimulate amyloid fibril formation. ${ }^{45}$ SDS is highly used to induce amyloid fibril formation but cationic surfactant-induced amyloid fibrillation is less studied. ${ }^{46}$ Cationic gemini surfactants have two positively charged head groups and two hydrophobic tails but their amyloid inducing property is less reported. There are few reports about the modulation of amyloid fibrillogenesis in $A \beta$ (1-40) peptide by a positively charged gemini surfactant. ${ }^{47}$ The two cationic gemini surfactants with the same charge on head and similar tail lengths but linked with different carbon chain spacer i.e., C5 and C6 (C5 and C6) are found to stimulate amyloidosis in concanavalin A, but the C6 spacer gemini surfactant induces bigger size aggregates compared to the C5 gemini surfactant. ${ }^{25}$

In this study, we have extensively explored the effect of cationic gemini surfactant $\mathrm{C}_{16} \mathrm{C}_{4} \mathrm{C}_{16} \mathrm{Br}_{2}$ on BLC protein fibrillation by exploiting different spectroscopic and computational techniques and the cytotoxicity effect of gemini was also explored. The RLS results suggest that BLC form aggregates in the presence of low concentrations of $\mathrm{C}_{16} \mathrm{C}_{4} \mathrm{C}_{16} \mathrm{Br}_{2}$ surfactant $(2-150.0 \mu \mathrm{M})$. However, concentrations above than $150.0 \mu \mathrm{M}$ cause a slight decrease in aggregation. The RLS results suggest that the $\mathrm{C}_{16} \mathrm{C}_{4} \mathrm{C}_{16} \mathrm{Br}_{2}$ surfactant induces lower sizes aggregates in the presence of lower $\mathrm{C}_{16} \mathrm{C}_{4} \mathrm{C}_{16} \mathrm{Br}_{2}$ concentrations at and as the concentrations of $\mathrm{C}_{16} \mathrm{C}_{4} \mathrm{C}_{16} \mathrm{Br}_{2}$ surfactant increases, the size of BLC aggregation is also increased. Similar RLS pattern was 


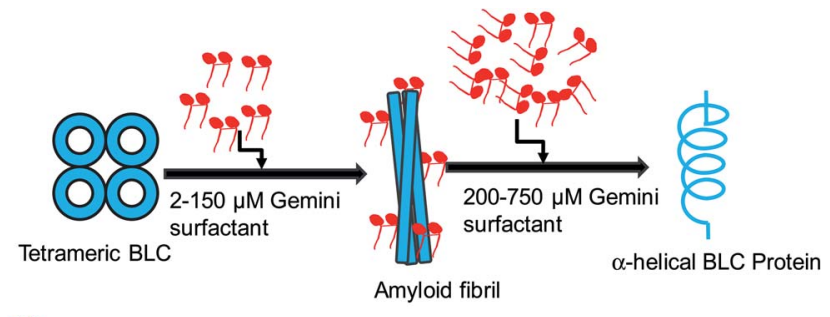

\% BLC protein

9 Gemini Surfactant

Amyloid Fibril

8 -helical BLC Protein

Fig. 9 Graphical representation of $\mathrm{C}_{16} \mathrm{C}_{4} \mathrm{C}_{16} \mathrm{Br}_{2}$-induced amyloid fibrillation followed by conformational transition.

reported for SDS and CTAB is inducing aggregation induction in hen egg white egg-white lysozyme. ${ }^{48}$ Tertiary structure modification of $\mathrm{BLC}$ in the presence of $\mathrm{C}_{16} \mathrm{C}_{4} \mathrm{C}_{16} \mathrm{Br}_{2}$ was also characterized. The fluorescence intensity of BLC dropped significantly in the presence of low concentrations of $\mathrm{C}_{16} \mathrm{C}_{4} \mathrm{C}_{16} \mathrm{Br}_{2}$, indicating aggregation of BLC. The possible cause for the decrease in fluorescence intensity is the movement of tryptophan residues into a more hydrophobic environment. The fluorescence intensity increased along with a red shift in wavelength maximum observed in the presence of slightly higher $\mathrm{C}_{16} \mathrm{C}_{4} \mathrm{C}_{16} \mathrm{Br}_{2}$ concentrations. The increase in fluorescence intensity and red shift in wavelength maximum is attributed to the tryptophan residues of BLC, which become exposed to a polar environment because of the unfolding of the tertiary structure. The fluorescence intensity of BSA was reduced in the presence of $\mathrm{C}_{16} \mathrm{C}_{4} \mathrm{C}_{16} \mathrm{Br}_{2}{ }^{49}$ The nature of BLC aggregates was also characterized by ThT dye binding. ThT binding is used to distinguish the nature of protein aggregates. $\mathrm{C}_{16} \mathrm{C}_{4} \mathrm{C}_{16} \mathrm{Br}_{2^{-}}$ induced BLC aggregates displayed a huge increase in ThT fluorescence intensity, confirming the amyloid structure of BLC aggregates. In a previous report, the ThT fluorescence intensity at $485 \mathrm{~nm}$ significantly increased because of the formation of amyloid fibril when HSA was treated with $60 \%(\mathrm{v} / \mathrm{v})$ ethanol and heated at $65{ }^{\circ} \mathrm{C}$ for $6 \mathrm{~h} .{ }^{50}$ The secondary structural conversion and TEM imaging data also support that $\mathrm{C}_{16} \mathrm{C}_{4} \mathrm{C}_{16} \mathrm{Br}_{2}$-induced aggregates have a well-defined amyloid structure. The $\alpha$-helical structure of proteins turn to $\beta$-structures ( $\beta$-sheeted and cross $\beta$ sheet) and random coils when proteins form aggregates or amyloid fibril structure. ${ }^{51}$ An interesting secondary structural transformation was also observed when $\mathrm{C}_{16} \mathrm{C}_{4} \mathrm{C}_{16} \mathrm{Br}_{2}$ and $\mathrm{BLC}$ interacted. The $\alpha$-helical structure of $\mathrm{BLC}$ decreased in the presence of low $\mathrm{C}_{16} \mathrm{C}_{4} \mathrm{C}_{16} \mathrm{Br}_{2}$ concentrations but increased in the presence of non-aggregating $\mathrm{C}_{16} \mathrm{C}_{4} \mathrm{C}_{16} \mathrm{Br}_{2}$ concentrations as shown in Table 1. This observation confirmed that low concentrations of $\mathrm{C}_{16} \mathrm{C}_{4} \mathrm{C}_{16} \mathrm{Br}_{2}$ surfactant induce amyloid fibrillation in BLC while higher concentrations change the BLC conformation. The spectroscopic results were supported by the in silico computational observation that $\mathrm{C}_{16} \mathrm{C}_{4} \mathrm{C}_{16} \mathrm{Br}_{2}$ interact with BLC through hydrophobic and electrostatic forces, and thus perturbs its dynamics with solvent molecules. The results of RMSD and RMSF suggest that the interaction between $\mathrm{C}_{16} \mathrm{C}_{4} \mathrm{C}_{16} \mathrm{Br}_{2}$ and $\mathrm{BLC}$ was stable in nature. Conversely, the results of $R_{\mathrm{g}}$ and SASA indicate that BLC undergoes a partial unfolding when binding to $\mathrm{C}_{16} \mathrm{C}_{4} \mathrm{C}_{16} \mathrm{Br}_{2}$.

The cytotoxicity data suggest that $\mathrm{C}_{16} \mathrm{C}_{4} \mathrm{C}_{16} \mathrm{Br}_{2}$ surfactant at low concentrations causes cytotoxicity in the cancerous cell line (A549). The imaging techniques result suggests that the morphology of the cancerous cell was significantly changed in the presence of the $\mathrm{C}_{16} \mathrm{C}_{4} \mathrm{C}_{16} \mathrm{Br}_{2}$ surfactant. The possible reason for the toxicity of the $\mathrm{C}_{16} \mathrm{C}_{4} \mathrm{C}_{16} \mathrm{Br}_{2}$ surfactant is due to higher hydrophobicity and presence of positively charged heads. The electrostatic interactions occurred between cationic head of the gemini surfactant and the negatively charged centers of the plasma membrane. The electrostatic and hydrophobicity interactions of the gemini surfactant destabilize the integrity of the plasma membrane which leads to the leaking and death of the cell. The antibacterial activity and cytotoxicity effect of different spacer lengths of gemini surfactant was also seen and reported that the increase in spacer length of gemini surfactant causes more antibacterial and toxicity in the cell. ${ }^{43}$

The detailed mechanism of $\mathrm{C}_{16} \mathrm{C}_{4} \mathrm{C}_{16} \mathrm{Br}_{2}$ induced amyloid fibrillation is presented in Fig. 9. BLC is a folded tetramer at $\mathrm{pH}$ 7.4 and all the subunits are arranged in defined shape. The polar amino acids are lie on the surface of the protein. The negatively charged amino acids (aspartate and glutamate) are present in the anionic form while positively charged amino acids are neutral at $\mathrm{pH}$ 7.4. When adding low concentrations of $\mathrm{C}_{16} \mathrm{C}_{4} \mathrm{C}_{16} \mathrm{Br}_{2}$ at this $\mathrm{pH}$, the positively charged head groups of $\mathrm{C}_{16} \mathrm{C}_{4} \mathrm{C}_{16} \mathrm{Br}_{2}$ interact with the negatively charged amino acids and perturb the BLC-solvent interaction. Consequently, hydrophobic residues of BLC become exposed to the solvent increasing hydrophobic interactions between BLC and $\mathrm{C}_{16} \mathrm{C}_{4} \mathrm{C}_{16} \mathrm{Br}_{2}$. The perturbation of BLC-solvent interaction is due to electrostatic interactions and increased hydrophobic interaction making a suitable environment for BLC to form amyloid fibrils. However, the amyloid fibrillation did not occur in the presence of higher concentrations of $\mathrm{C}_{16} \mathrm{C}_{4} \mathrm{C}_{16} \mathrm{Br}_{2}$ because the charge neutralization is unbalance. Interestingly, the secondary structure ( $\alpha$-helix) of BLC again regain its original form.

\section{Conclusions}

This work monitored, the effect of cationic gemini surfactant $\mathrm{C}_{16} \mathrm{C}_{4} \mathrm{C}_{16} \mathrm{Br}_{2}$ on the fibrillogenesis and the secondary structural modification of BLC. All spectroscopic and microscopic results demonstrated that a low concentration of $\mathrm{C}_{16} \mathrm{C}_{4} \mathrm{C}_{16} \mathrm{Br}_{2}$ induces amyloid fibrillation of BLC. Molecular docking results suggest that the positively charged heads of $\mathrm{C}_{16} \mathrm{C}_{4} \mathrm{C}_{16} \mathrm{Br}_{2}$ are in close contact with the negatively charged center of the protein $\left(\mathrm{O}^{\delta 1}\right.$ of Asp127) through electrostatic interactions, while the hydrophobic tails of $\mathrm{C}_{16} \mathrm{C}_{4} \mathrm{C}_{16} \mathrm{Br}_{2}$ interacts with the hydrophobic residues of $\mathrm{BLC}$ (Val125). Molecular dynamics simulation also suggests that the binding of $\mathrm{C}_{16} \mathrm{C}_{4} \mathrm{C}_{16} \mathrm{Br}_{2}$ to $\mathrm{BLC}$ was stable, even though it causes a partial unfolding of BLC. These interplay of electrostatic and hydrophobic interactions between BLC and $\mathrm{C}_{16} \mathrm{C}_{4} \mathrm{C}_{16} \mathrm{Br}_{2}$ result in amyloid fibrillation of BLC. However, 
higher concentrations of $\mathrm{C}_{16} \mathrm{C}_{4} \mathrm{C}_{16} \mathrm{Br}_{2}$ did not cause the amyloid fibrillation because the electrostatic interaction is disturbed by the excessive availability of positive charges. The cytotoxicity of the $\mathrm{C}_{16} \mathrm{C}_{4} \mathrm{C}_{16} \mathrm{Br}_{2}$ surfactant was noticed in A549 cells as tested by MTT assay. The morphology of cells was changed and percent cell viability decreases with increase in the concentrations of $\mathrm{C}_{16} \mathrm{C}_{4} \mathrm{C}_{16} \mathrm{Br}_{2}$ surfactant. These results may help to understand the mechanism of amyloid fibrillation and start the development of reagent that perturb the electrostatic as well as hydrophobic interactions to control amyloid fibrillation.

\section{Authorship contribution}

Javed Masood Khan: conceptualization, data curation, formal analysis, funding acquisition, investigation, methodology, project administration, resources, software, supervision, validation, writing - original draft, writing - review \& editing. Ajamaluddin Malik: resources, formal analysis, methodology, writing - review \& editing. Md Tabish Rehman: software, visualization, methodology, investigation, writing - review \& editing. Mohamed F. AlAjmi: software and visualization. Mohammad Z Ahmed: formal analysis and writing - review \& editing. Md. Khalid Anwer: formal analysis and writing - review \& editing. Rizwan Hasan Khan: methodology, resources, supervision, writing - review \& editing.

\section{Abbreviations}

$\begin{array}{ll}\text { BLC } & \text { Bovine liver catalase } \\ \text { DLS } & \text { Dynamic light scattering } \\ \text { TEM } & \text { Transmission electron microscopy } \\ \text { ThT } & \text { Thioflavin-T }\end{array}$

\section{Conflicts of interest}

The authors declare that they do not any known competing financial interests or personal relationships that could have appeared to influence the work reported in this paper.

\section{Acknowledgements}

The authors extend their appreciation to the Deanship of Scientific Research at King Saud University for funding the work through the research group project no. RG-1440-099. The authors thank the Deanship of Scientific Research and RSSU at King Saud University for their technical support.

\section{References}

1 J. W. Kelly, Curr. Opin. Struct. Biol., 1998, 8, 101-106.

2 B. O'Nuallain, S. Shivaprasad, I. Kheterpal and R. Wetzel, Biochemistry, 2005, 44, 12709-12718.

3 G. Wei, Z. Su, N. P. Reynolds, P. Arosio, I. W. Hamley, E. Gazit and R. Mezzenga, Chem. Soc. Rev., 2017, 46, 4661-4708.

4 F. Chiti and C. M. Dobson, Nat. Chem. Biol., 2009, 5, 15-22.
5 T. P. Knowles, J. F. Smith, A. Craig, C. M. Dobson and M. E. Welland, Phys. Rev. Lett., 2006, 96, 238301.

6 V. J. McParland, N. M. Kad, A. P. Kalverda, A. Brown, P. Kirwin-Jones, M. G. Hunter, M. Sunde and S. E. Radford, Biochemistry, 2000, 39, 8735-8746.

7 M. Hernandez, Y. Hu and J. R. Kim, Chem. Commun., 2013, 49, 10712-10714.

8 Z. Jiang and J. C. Lee, J. Mol. Biol., 2014, 426, 4074-4086.

9 T. A. Pertinhez, M. Bouchard, R. A. Smith, C. M. Dobson and L. J. Smith, FEBS Lett., 2002, 529, 193-197.

10 S. Yamamoto, K. Hasegawa, I. Yamaguchi, S. Tsutsumi, J. Kardos, Y. Goto, F. Gejyo and H. Naiki, Biochemistry, 2004, 43, 11075-11082.

11 M. A. Ismael, J. M. Khan, A. Malik, M. A. Alsenaidy, S. Hidayathulla, R. H. Khan, P. Sen, M. Irfan and A. M. Alsenaidy, Colloids Surf., B, 2018, 170, 430-437.

12 T. Ookoshi, K. Hasegawa, Y. Ohhashi, H. Kimura, N. Takahashi, H. Yoshida, R. Miyazaki, Y. Goto and H. Naiki, Nephrol., Dial., Transplant., 2008, 23, 3247-3255.

13 M. Jafari and F. Mehrnejad, PLoS One, 2016, 11, e0165213.

14 M. So, A. Ishii, Y. Hata, H. Yagi, H. Naiki and Y. Goto, Langmuir, 2015, 31, 9973-9982.

15 M. N. Jones, H. A. Skinner and E. Tipping, Biochem. J., 1975, 147, 229-234.

16 J. M. Khan, M. S. Khan, M. S. Ali, N. A. Al-Shabib and R. H. Khan, RSC Adv., 2016, 6, 38100-38111.

17 M. S. Kamal, J. Surfactants Deterg., 2016, 19, 223-236.

18 M. N. Maithufi, D. J. Joubert and B. Klumperman, Energy Fuels, 2011, 25, 162-171.

19 M. T. Garcia, O. Kaczerewska, I. Ribosa, B. Brycki, P. Materna and M. Drgas, Chemosphere, 2016, 154, 155-160.

20 A. Laatiris, M. el Achouri, M. R. Infante and Y. Bensoudaa, Microbiol. Res., 2008, 163, 645-650.

21 A. R. Tehrani-Bagha, H. Oskarsson, C. G. van Ginkel and K. Holmberg, J. Colloid Interface Sci., 2007, 312, 444-452.

22 Y. Pi, Y. Shang, C. Peng, H. Liu, Y. Hu and J. Jiang, Biopolymers, 2006, 83, 243-249.

23 Kabir-ud-Din, M. A. Rub and A. Z. Naqvi, J. Phys. Chem. B, 2010, 114, 6354-6364.

24 J. M. Khan, M. S. Khan, A. Qadeer, M. A. Alsenaidy, A. Ahmed, N. A. Al-Shabib and R. H. Khan, Colloids Surf., A, 2017, 522, 494-502.

25 J. M. Khan, M. R. Khan, P. Sen, A. Malik, M. Irfan and R. H. Khan, J. Mol. Liq., 2018, 269, 796-804.

26 M. R. Murthy, T. J. Reid 3rd, A. Sicignano, N. Tanaka and M. G. Rossmann, J. Mol. Biol., 1981, 152, 465-499.

27 P. Nicholls, I. Fita and P. C. Loewen, Adv. Inorg. Chem., 2001, 51, 51-106.

28 G. O. Fruhwirth, A. Paar, M. Gudelj, A. Cavaco-Paulo, K. H. Robra and G. M. Gubitz, Appl. Microbiol. Biotechnol., 2002, 60, 313-319.

29 M. Shamsipur, M. Asgari, M. G. Maragheh and A. A. MoosaviMovahedi, Bioelectrochemistry, 2012, 83, 31-37.

30 K. Prakash, S. Prajapati, A. Ahmad, S. K. Jain and V. Bhakuni, Protein Sci., 2002, 11, 46-57. 
31 N. A. Al-Shabib, J. M. Khan, A. Malik, M. A. Alsenaidy, M. T. Rehman, M. F. AlAjmi, A. M. Alsenaidy, F. M. Husain and R. H. Khan, J. Mol. Liq., 2018, 269, 511-520.

32 M. F. AlAjmi, M. T. Rehman, A. Hussain and G. M. Rather, Int. J. Biol. Macromol., 2018, 116, 173-181.

33 M. T. Rehman, H. Shamsi and A. U. Khan, Mol. Pharm., 2014, 11, 1785-1797.

34 M. T. Rehman, S. Ahmed and A. U. Khan, J. Biomol. Struct. Dyn., 2016, 34, 1849-1864.

35 G. J. Martyna, D. J. Tobias and M. L. Klein, J. Chem. Phys., 1994, 101, 4177-4189.

36 S. Rashtbari, G. Dehghan, R. Yekta and A. Jouyban, Bioimpacts, 2017, 7, 147-153.

37 W. Eventoff, N. Tanaka and M. G. Rossmann, J. Mol. Biol., 1976, 103, 799-801.

38 I. Fita and M. G. Rossmann, J. Mol. Biol., 1985, 185, 21-37. 39 T. J. Reid 3rd, M. R. Murthy, A. Sicignano, N. Tanaka, W. D. Musick and M. G. Rossmann, Proc. Natl. Acad. Sci. U. S. A., 1981, 78, 4767-4771.

40 B. K. Vainshtein, W. R. Melik-Adamyan, V. V. Barynin, A. A. Vagin and A. I. Grebenko, Nature, 1981, 293, 411-412.
41 B. Brycki and A. Szulc, PLoS One, 2014, 9, e84936.

42 B. Brycki, Pol. J. Microbiol., 2010, 59, 227-231.

43 S. S. Zhang, S. P. Ding, J. Yu, X. R. Chen, Q. F. Lei and W. J. Fang, Langmuir, 2015, 31, 12161-12169.

44 Y. Wang, B. Jia, M. You, H. Fan, S. Cao, H. Li, W. Zhang and G. Ma, J. Phys. Chem. B, 2019, 123, 6200-6211.

45 M. K. Siddiqi, Y. E. Shahein, N. Hussein and R. H. Khan, J. Mol. Struct., 2016, 1119, 12-17.

46 A. Abelein, J. D. Kaspersen, S. B. Nielsen, G. V. Jensen, G. Christiansen, J. S. Pedersen, J. Danielsson, D. E. Otzen and A. Graslund, J. Biol. Chem., 2013, 288, 23518-23528.

47 M. Cao, Y. Han, J. Wang and Y. Wang, J. Phys. Chem. B, 2007, 111, 13436-13443.

48 S. K. Chaturvedi, J. M. Khan, M. K. Siddiqi, P. Alam and R. H. Khan, Int. J. Biol. Macromol., 2016, 83, 315-325.

49 Y. Li, X. Wang and Y. Wang, J. Phys. Chem. B, 2006, 110, 8499-8505.

50 N. K. Pandey, S. Ghosh and S. Dasgupta, J. Phys. Chem. B, 2010, 114, 10228-10233.

51 J. Juarez, S. G. Lopez, A. Cambon, P. Taboada and V. Mosquera, J. Phys. Chem. B, 2009, 113, 10521-10529. 